which there were obscure abdominal pains and constipation where no lead line was detected, either because the teeth were absent or because it was not looked for. I was quite unable to find the source of the intoxication in the three instances in which I carefully looked for it. In one case I had the tea examined, but with a negative result. During this autumn I have seen nine cases in which the patients had a well-marked blue line, as well as several others in which there were abdominal pains and constipation. Having practically excluded every other probable source, I again submitted samples of tea to Mr. Arthur Angell, Ph.D., F.I.C., of the County Laboratory, Southampton, and he reports as follows :-

No. 1.-Loose tea as supplied to four of my patients. (This, the village shopman assured me, he received from London in large paper bags, with no lead paper.) "In this sample lead was distinctly present."

No. 2.-A quarter of a pound packet in thick lead paper. "In this sample distinct traces of lead were found."

No. 3.-A quarter of a pound packet not in a lead package. "Here the faintest possible reaction for lead was found."

No. 4.-A quarter of a pound packet in lead paper. this sample a larger quantity of lead was found than in any of the other samples."

Nos. 1, 2, and 3 were bought by me at a village shop. No. 4 was taken from a patient's house.

The symptoms have in all the cases been abdominal, with marked pallor, and the addition of severe facial neuralgia in one case, pains in the limbs in another, and gout in a third. There has been vomiting in two or tbree cases and diarrhcea (possibly, however, due to pills, of which the cottagers partake so freely) in one or two. One patient had a serious relapse after about a fortnight, but he may, of course, have reintoxicated himself. I have seen no wrist-drop or eye symptoms. In three instances both parents bare been affected at the same time, and in no case have there been any symptoms in children. They, however, usually hare weak tea in small quantities. I hare full notes of the quantities drunk in two or three cases, which may be of interest when I receive the quantitative analysis from Mr. Angell, who is fully investigating this matter; but I hasten to send his preliminary report.

weyhill, Andover.

\section{BENZOLE IN INFLUENZA.}

By William Robertson, M.D. Glasg., SLRGEON TO THR THROAT AND EAR HOSPITAL, NEWC.ISTLE-ON-TYNE.

THE majority of the cases of influenza I have met with lately I have treated with benzole, and with the best results. I have already in the columns of THE LANCET referred to the several ways in which the drug can be administered. In every case the drug has been well tolerated. The cases treated have all shown the usual symptoms met with in influenzaviz., rapid onset of attack, temperature ranging from $101^{\circ}$ to $103^{\circ} \mathrm{F}$, quick pulse, shivering, pain in the head and down the back, dull-red injection of fauces, \&c. The drug was administered in the form of an emulsion in lemonade, fire minims to be taken every two hours and a half. As a rule, in about two hours after the first dose the general discomfort had disappeared, and within the first twenty-four hours the temperature was observed to be normal. Rarely, indeed, was any further pyrexia to be noticed. Convalescence was usually rapid, with very little of the debility so noticeable when routine treatment was employed. As a check experiment, and when two patients were observed in one house, one would be placed upon benzole and the other on, for example, liquor ammoniæe acetatis, \&c. As a rule the next morning the patient taking benzole would be found to be free from fever, with the pulse normal, \&c.; while the other would still be feverish and in general discomfort. The patients usually showed no very severe pulmonary symptoms, but a few had a temperature of between $103^{\circ}$ and $104^{\circ}$, and in each case within twenty-four hours the temperature was normal. This result was met with in influenza, and the equally good results of its action in whoopingcough determine the value of benzole as a pulmonary antiseptic.

Osborne-road, Newcastle.on-Tyne.

\section{A}

OF

\section{HOSPITAL PRACTICE, BRITISH AND FOREIGN.}

Nulla autem est alia pro certo noscendi via, nisi quamplurimas et mos borum et dissectionum historias, tum aliorum tum proprias collecta habere, et inter se comparare.-MorgagnI De Sed. et Caus. Morb.,
lib. iv. Procemium.

\section{GUY'S HOSPITAL.}

A CASE OF CARDIAC FAILURE DURING THE ADMINISTRA TION OF ETHER.

(Under the care of Mr. DAVIES-ColLEY.)

The following account of the occurrence of serious syncope during the administration of ether will be read with consider. able attention, for the profession is not accustomed to regard such a complication as at all likely to occur during inhalation of this drag; in fact, many surgeons prefer ether to chloro form for anæsthetic purposes, because of the absence of liability to accidents of this kind. We shall be pleased to receive communications on this subject from those who may have had similar experiences. For the following report we are indebted to Mr. T. D. Lister, house surgeon, and for the remarks to Dr. Silk, assistant anæsthetist.

A labourer forty-eight years of age, not bronchitic and with no signs of organic disease or alcoholic degeneration, was admitted to the accident ward of Guy's Hospital on the morning of Oct. 14th suffering from a severe compound fracture of the left leg. There were two wounds, the larger, on the front of the leg, having the upper fragment of the tibia projecting over the skin at the lower end of the wound. As this was irreducible by extension without an anæsthetic its was resolred to administer ether, and the anæsthesia was maintained during an incision of the skin to enable reduction to take place, cleansing, and final setting of the limb in a Croft's splint. Clover's apparatus was used, two ounces on ether being put into the previously empty container. The patient took the anæsthetic well, and the stage of excitement was very brief. The container was gradually moved round until the indicator pointed to " 3 " and full anæsthesia was. induced in rather less than four minutes. The head was then turned to the right to facilitate the removal, from time to time, of the small quantity of mucus that formed, This was, if anything, less than usual. The indicator was gradually brought back nearly to " 1 ," and, to ensure a further diminution in the strength of the vapour, two or three aerial respirations were alternated with every eight or nine taken through the inbaler. At the end of half an hour slight signs of returning consciousness, of whicb the patient afterwards had no knowledge, made it necessary to replenish the inhaler. The small quantity of aqueous ethereal fluid in the container was poured out, and two ounces of fresh ether were added. Full anæsthesia was again induced, during which process the breathing became noisy for a few minutes, and the indicator was again gradually brought back to the " 1 " mark. The anæsthetic condition then appeared to be quite normal. At the end of a second half hour, when the process of setting the limb was nearly completed, suddenly and without warning or apparent cause, and while in a condition of complete anæesthesia, the patient became intensely pale, his lips blue, and his respirations. rapidly failed. The pupils remained contracted; there was no retching. The fauces and upper aperture of the larynz were clear. The cardiac apex beat could not be felt, and no arterial pulse could be detected anywhere. The foot of the bed was raised about two feet, and artificial respiration slowly and deeply performed, air entering quietly and without. difficulty. After twelve or thirteen movements, occupying nearly a minute, one small, very short inspiratory gasp occurred? automatically. Soon afterwards the apex beat became again feebly palpable, and artificial respiration being continued for a further nine or ten movements, another short inspiration took place, and was followed by very small but gradually increasing respirations, expiration being then assisted by pressure on the thoracic wall. There was no vomiting at any time. Tha 